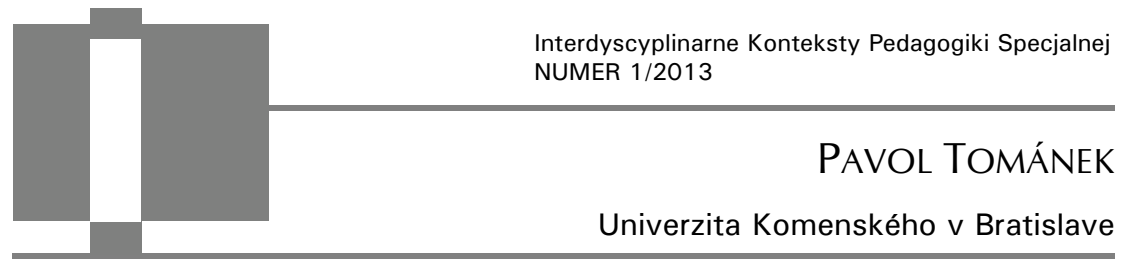

\title{
Novovznikajúce formy rodinného života na Slovnensku
}

\begin{abstract}
Tománek Pavol, New emerging forms of family life in Slovakia [Nowe rozwijające się formy życia rodzinnego w Słowacji]. Interdyscyplinarne Konteksty Pedagogiki Specjalnej, nr 1, Poznań 2013. Pp. 101-119 Adam Mickiewicz University Press. ISBN 978-83-232-2539-3.

The present study deals with the family, parenting and the current form of creating families. The work provides insight into the phenomenon of current single, mingle and patchwork families.
\end{abstract}

KEY WORDS: family, education, single family, mingle family, patchwork family

\section{Úvod}

Pedagogika, ktorá je vedou o výchove a vzdelávaní, v súčasnosti akoby „seba samu“ potrebovala vychovávat'. Na jednej strane sa v spoločnosti preferuje vzdelanie ako základ budúcich generácií, no na strane druhej badat' absenciu výchovných systémov, ktorých základy sa kladú práve $\mathrm{v}$ rodine. Rodina je základným edukačným prostredím pre diet’a, či dospievajúcu osobnost'. V rodine sa dávajú základy morálky, slušnosti, spoločenských pravidiel. Je miestom, kde rodičia nastavujú mantinely správania sa, kde prichádza k rastu a kultivácií osobností každej spoločnosti. S obl'ubou sa prezentuje, že súčasná rodina je $\mathrm{v}$ kríze, že výchova prechádza búrlivým 
obdobím. Podstata problému je však hlbšia. Rodinná výchova je integrujúcim edukačným predmetom, ktorý kultivuje mladú dospievajúcu osobnost'. Mladí l'udia dnešnej doby často nevedia, čo ich čaká v živote. Sú vyštudovaní, no chýbajú im istoty. Rodina, ktorá mala ako prvá inštitúcia zasadit' základy všetkého (výchova, tradície, viera...), často sama potrebuje istý druh reštaurovania, či sanácie. Doba, ktorú tvoríme, neustále zdôrazňuje funkcie rodiny a rodinného života. Pravdou však zostáva skutočnost', že spoločnost' by sa mala v dnešnej dobe viac zaoberat' funkčnost'ou rodiny ako jej funkciami. Otázka tzv. patchwork rodín, ktoré sa postupne začínajú vytvárat' aj na Slovensku, je o to viac alarmujúcim faktom a výzvou $\mathrm{k}$ riešeniu azda aj celospoločenského handicapu. $\mathrm{V}$ predkladanej štúdii sa chcem zamerat' na aktuálne novovytvárajúce podoby rodiny, ich charakteristiku, nástrahy a „prevenciu.“

\section{Rodina}

Rodinou ${ }^{1}$ rozumieme predovšetkým sociálnu skupinu, ktorá je zložená z dvoch alebo viacerých osôb žijúcich spolu $\mathrm{v}$ jednej domácnosti, ktoré sú spojené manželskými, pokrvnými alebo adoptívnymi zväzkami. Možno ju charakterizovat' aj ako primárnu, neformálnu a intímnu sociálnu skupinu a základnú spoločenskú jednotku, ${ }^{2}$ ktorá je často považovaná za kolísku l'udstva a výchovy. Rodina $^{3}$ sa charakterizuje aj ako malá spoločenská skupina, založená z dvoch dospelých členov opačného pohlavia a ich potomkov. Je to prvé sociálne prostredie, ako i výchovná inštitúcia prvoradého významu, v ktorej sa jedinec ocitá. Rodina je spoločensky schválená forma partnerských vzt'ahov dvoch rovnoprávnych, rovnocenných a milujúcich sa l'udí, spojená pevným príbu-

1 P. Tománek, Teoretické východiská rodinnej výchovy, Brno, Tribun 2012.

2 V. Tamášová, Teória a prax rodinnej edukácie, Ivanka pri Dunaji, Axima 2007, s. 12.

3 J. Prevendárová, Rodina s postihnutým dietatom, Nové Zámky, Psychoprof spol. s r. o., Artus 1998, s. 11. 
zenským a pokrvným zväzkom. Jej znakom je intímne spolužitie v jednej domácnosti, spolupráca, pomoc a kooperácia jej členov. Atmosféra rodinného prostredia je daná vzájomnými vzt'ahmi medzi rodičmi a ostatnými členmi rodiny. Diet'a sa formuje podl'a rodinných vzt'ahov, podl'a rodinného prostredia, v ktorom vyrastá. To, čo diet́a v rodine vidí, to aj napodobňuje. ${ }^{4}$ Dospelí, najmä rodičia sú preň vzorom v akomkol'vek konaní. Rodina je prirodzenou sociálnou skupinou, základnou bunkou spoločnosti. Združuje l'udí v intímnej jednote na podklade pokrvnej príbuznosti. Všade tam, kde muž a žena žijú spolu, bývajú pod jednou strechou, spoločne hospodária a vychovávajú deti, hovoríme o rodine. $\mathrm{V}$ nej si diet'a vytvára vlastnú identitu a typickú kultúru prezentovanú vlastnými tradíciami, hodnotami a konvenciami. Pokrvná príbuznost', rodinné ekonomické záujmy ako aj výchova detí nevystihujú však ešte dostatočne podstatu rodiny. Rodina totiž nie je schopná existovat' izolovane od spoločnosti, vždy je súčast'ou širšej sociálnej jednotky, ktorej normy, kultúra, tradície a náhl'ady zasahujú aj rodinu. Rodina je preto prvým článkom ret’azca, ktorý spája jedinca so spoločnost'ou. Rodina je prvým skúšobným prostredím. ${ }^{5} \mathrm{~V}$ súčasnej dobe však badáme, že tradičné základné znaky rodiny, sa akoby zmenšovali, zosmiešňovali alebo aj atomizovali. Univerzalita a tradicionalita sú pravdepodobne dva základné znaky rodiny, ktoré pretrvávajú doteraz. Konzervatizmus je často vytláčaný legalizovanými heterosexuálnymi (čiže konkubinát) či dokonca homosexuálnymi zväzkami. Sakralita rodín je často atomizovaná formou spolunažívania, ktorú dnešná spoločnost' označuje termínom single rodina alebo aj mingle rodina. Azylyta je len "popoluškou“ vzt'ahov, ktoré majú byt' normálne, vyvážené a zmysluplné. Azylyta je typickým znakom pre tzv. patchwork rodiny. Všetky tieto súčasné podoby rodín rozoberieme $\mathrm{v}$ nasledujúcich kapitolách a podkapitolách.

${ }^{4}$ D. Kostrub, Diet'a - (ako) autonómny a kompetentný subjekt, Žiar nad Hronom, Aprint 2007, s. 15-18.

5 V. Tamášová, Teória a prax rodinnej edukácie, Ivanka pri Dunaji, Axima 2007, s. 37 . 


\section{Výchova $v$ rodine}

Rodina je významným prostredím výchovy. Výchova $\mathrm{v}$ rodine sa neobmedzuje len na predškolský a mladší školský vek diet'at'a, ale trvá až po ukončenie vzdelávania. Ba spokojne môžeme povedat', že i v d'alšom samostatnom živote novovzniknutých mladých rodín (ak berieme do úvahy otázku výchovy starými rodičmi). Vel'mi dôležitou je rodinná výchova $\mathrm{v}$ predškolskom veku a $\mathrm{v}$ období dospievania mladých l'udí. Počas dospievania sa zintenzívňuje duševný život, ale aj formovanie vlastných záujmov. Plnenie výchovných funkcii rodiny predpokladá určité podmienky. Rodičia sú považovaní za prvých a hlavných vychovávatel'ov svojich detí. Rodina zasa za prvotnú inštitúciu, v ktorej prebieha proces výchovy. Napriek tomu, že na správnu výchovu neexistuje jednotný - optimálny návod, musí sa uskutočňovat' premyslene a cielavedome. ${ }^{6}$ Východiskom pre konanie diet'at'a stáva sa správanie rodičov. Ním je možné docielit', aby deti boli čestné, mali úctu $\mathrm{k}$ iným l'ud'om, pravdovravné, vedeli rozlíšit' dobro od zla a pod. Výchova je neodmyslitel'nou súčast'ou každého jedinca, spoločnosti a kultúry. Nie je „rezervovaná" len rodičom, učitel'om alebo vychovávatel'om, ale aj spoločnosti, v ktorej nielen vychovávam, ale som zároveň aj vychovávaný. Pod pojmom výchova rozumieme ovplyvňovanie, vd'aka ktorému chceme dosiahnut' zlepšenie, zdokonalenie, či dokonca zhodnotenie osobnosti vychovávaného. Zmysel každej výchovy spočiva $\mathrm{v}$ tom, aby sme pomohli vychovávanému získat' osobnostné vlastnosti, ktoré ho robia schopným samostatného a sociálne zodpovedného života. Osobnostné vlastnosti sú často ovplyvnitel'né vlastnou povahou každého jedinca, sociálnym prostredím, či dokonca aj kultúrou, ktorú sám vytvára a často aj kreatívne pretvára. Práve výchova má ovplyvňovat' aktérov výchovy (učitel', rodič, vychovávatel', ale aj vychovávaný), a to v každej dimenzii ich života, resp. telesnej, duchov-

${ }^{6}$ H. Rozjinajová, Základy rodinnej výchooy, Bratislava, SPN 1992, s. 34. 
nej, duševnej, spoločenskej, profesijnej, i morálnej. Podl'a R. Palouša7 je výchova zámerným a sústavným pôsobením l'udského jedinca (napr. vychovávatel'a) na druhého jedinca (vychovávaného). Upozorňuje na skutočnost', že táto výchova vedie ku vzniku relatívne trvalých zmien $\mathrm{v}$ správaní a prežívaní práve toho druhého jedinca. Funkčnost' výchovy ${ }^{8}$ spočíva $\mathrm{v}$ odovzdávaní posolstva mravných ideálov, noriem a pravidiel a v ich dodržiavaní. Výchova je podl'a R. Palouša ${ }^{9}$ novou nádejou, že sa l'udstvo obráti ku svojím povinnostiam, k pravej l'udskej povinnosti a l'udskej poctivosti. Ďalej dodáva, že táto nádej sa dá naplnit' cestou dôverného odovzdávania sa do náručia toho, koho človek neuznal, i ked' ho neustále viedol, a nemohol ho viest' inokade, iba cestou vyhnanca, pretože, ako R. Palouš hovorí, k návratu má dôjst' z vyhnanstva slobodného rozhodovania človeka (každého jedinca). Výchova je procesom, v ktorom je riadená životná aktivita človeka. ${ }^{10}$ Rodinná výchova je chápaná ako spoločensko-historický jav, ktorý nadobúda v období zvyšovania vedecko-technickej úrovne stále väčší význam. Prihliada na potreby dnešnej doby i na perspektívne potreby spoločnosti. Realizuje sa na základe zložitého komplexu podnetov (osobnost' rodičov, spôsob rodinného života, rodinná atmosféra, rodinné prostredie), ktoré majú socializačno-výchovné účinky. Rodinnú výchovu môžeme chápat' ako proces odovzdávania spoločenskohistorických skúseností s cielom pripravit' mladú generáciu na usporiadaný rodinný život a na prácu v nových spoločenských podmienkach. V minulosti sa deti vychovávali spontánne v rodinnom prostredí, pričom prevládala funkcionálna, mimovol'ná výchova, ktorú postupne doplňovala intencionálna, ciel'avedomá rodinná výchova, d’alej ciel'avedomá školská výchova a napokon aj rozličné vplyvy okolitého prostredia. Súčasná rodinná výchova je

7 R. Palouš, Čas výchovy, Praha, Státní pedagogické nakladatelství 1991, s. 53.

8 P. Tománek, Teoretické východiská rodinnej výchovy, Brno, Tribun 2012.

9 R. Palouš, Čas výchovy, Praha, Státní pedagogické nakladatelství 1991, s. 214.

10 A. Gogová - Š. Kročková - G. Pintes, Žiak, sloboda, výchova, Nitra, Vydavatel'stvo Michala Vaška 2004, s. 96. 
poznačená prakticizmom, uskutočňuje sa bez vymedzenia výchovných ciel'ov. Jej obsah určujú prevažne iba skutky diet'at'a, na ktoré rodičia bezprostredne reagujú. Výchova by sa však mala ovel'a viac zameriavat' na perspektívu, nemala by mat' teda len náhodný charakter. Preto konštatujeme, že rodinná výchova musí rozvíjat' osobnost' po stránke kognitívnej, afektívnej a psychomotorickej. ${ }^{11}$ Rozvoj emocionálnej stránky vedie $\mathrm{k}$ rozvoju sociálnej stránky osobnosti a prepojenie rozumovej, afektívnej a psychomotorickej je cestou $\mathrm{k}$ axiologickej, teda hodnotovej rovine.

\section{Súčasné podoby rodiny}

V nasledujúcej kapitole sa budeme zaoberat' konkrétnymi podobami vytvárania rodín v súčastnosti. Ciel'om nie len charakteristika týchto podôb rodín, ale aj poukázanie na ich negatívny dopad na spoločnost', rodinu, konkrétneho človeka.

\subsection{Rodina ako "single“}

V posledných rokoch vzrastá trend slobodných matiek, ktoré si zaobstarali diet'a „bez partnera“, respektíve od začiatku nepočítali s mužom, s ktorým diet’a majú, ako s otcom. Tým, že rastie počet rozvodov, sa zvyšuje aj počet l'udí, ktorí majú deti, ale nemajú partnera. Logickým vyústením tejto situácie je čím d'alej rozšírenejšia tzv. single rodina, ktorá je často označovaná aj sloganom: chcem diet'a - nechcem muža. ${ }^{12}$ Dalo by sa konštatovat', že ide o lobistické a hedonistické pohnútky ženy. Opak však je pravdou. Ženy sa často rozhodujú pre tento životný štýl preto, lebo doposial' si nikoho nenašli, s kým by spoločne trávili svoj život; po skúsenostiach mnohých týraných žien a rozvedených žien sa chcú týmto

\footnotetext{
11 Z. Matějček, Co děti nejvíc potřebují?, Praha, Portál 1995, s. 90.

12 P. Tománek, Teoretické východiská rodinnej výchovy, Brno, Tribun 2012, s. 84.
} 
spôsobom vyhnút' možným problémom a po tretie - chcú z tohto pragmatického vzt'ahu na skúšku vyjst' ako vít'azky, ktoré zostali tehotné. Dokonca, mnohé ženy si s mužmi podpíšu akúsi formu zmluvy, ${ }^{13}$ kde sa žena zaväzuje mužovi, že po narodení diet'at'a si nebude od neho žiadat' priznanie otcovstva a prípadné dávky na diet'a, l'udovo nazývané ako alimenty.

Dôvody, prečo l'udia zostávajú v tzv. single rodinách, sú:

- v dnešnej dobe dozrievajú psychicky mladí l'udia ovel'a neskôr, čo je dané aj dlhšou prípravou na budúce povolanie, pomalším osamostatňovaním a snahou spoznat' toho čo najviac. Mladí l'udia si často nevedia predstavit', že prvá láska či dlhší vzt'ah je konečnou zastávkou,

- I'udia, ktorí sú sami, sa málo viažu na jedno miesto, objavuje sa u nich túžba cestovat', spoznávat' nové kultúry, l'udí, vzdelávat' sa, žit' aktívne. Pravda, toto je možné robit' aj s partnerom, ale už sa človek musí tiež podriad'ovat' záujmom a potrebám druhého. A taký kompromis znamená tiež vediet' pol'avit' zo svojich požiadaviek,

- l'udia, ktorí sa usadia v rodinnom živote príliš skoro, môžu mat' pocit, že im niečo utieklo, že si nič neužili, a to môže skončit' aj rozpory a rozvratom rodiny.

Negatíva single rodín sú:

- l'udia, ktorí sú dlhšiu dobu bez partnera majú sklony k depresiám (ktoré sa s blížiacim sa jeseňou prehlbujú), k bolestiam hlavy, bývajú častejšie unavení, a preto sú aj náchylnejší k chorobám,

- niektorí l'udia sa môžu tiež nezodpovedne stavat' k životu, nevedia prevziat' život „do svojich rúk“, slobodu berú ako zámienku na nadväzovanie stále nových krátkodobých vztáahov,

- l'udia si môžu tiež menej verit', preto môžu odmietat' bližšie kontakty. Niekedy tiež pre samotné budovanie kariéry l'udia zabúdajú na to, že potrebujú kontakt s druhými.

${ }^{13}$ Dostupné: http:/ / www.familienratgeber-nrw.de/index.php?id=1891 [cit. 2.8. 2012]. 


\subsection{Rodina ako "mingle“}

Pomenovanie mingle vzniklo kombináciou protichodných a navzájom sa vylučujúcich výrazov "married but single“ - vydatá/ženatý, ale slobodná/slobodný. Tento trend prišiel do Európy začiatkom tretieho tisícročia zo Severnej Ameriky, kde sa už naplno udomácnil. V podstate ide o žitie spolu v rámci manželského zväz$\mathrm{ku}$, no zároveň slobodným a nezáväzným spôsobom. Autorka E. Beck-Gernsheim ${ }^{14}$ dodáva, že

[...] nie je vôbec vylúčené (v takýchto rodinách), že manžel odíde za inou ženou (milenkou), s ktorou splodí diet'a. Manžel sa tomuto diet'at'u prizná, platí naň alimenty, no nechce sa rozviest'. Dokonca, často prinúti vlastnú manželku, aby tento stav rešpektovala a považovalo ho za normálny pre dnešnú dobu. Manželka tým samozrejme trpí, robí právne úkony. Manžel prichádza do vlastného domu, vyspí sa, poierie si veci, naje sa a opät' odchádza za svojou milenkou, ktorá ho očakáva. Ide v podstate o predstieranú zodpovednost' tak v prvom, ako i v druhom zväzku, ktorý manžel tvorí.

Pomenovanie mingle rodina teda v sebe zahŕňa vždy protichodné a klasicky zaužívané termíny. $\mathrm{V}$ rodinách sa tak môžeme stretnút s označením vydato-slobodná matka alebo ženato-slobodný otec (nem. verheiratet, ledig Vater/ verheiratet, Single-Frau). Úloha rodiny je vel'mi komplikovaná. Rodičia sú spolu, a nie sú spolu. Aj tvoria spoločne, aj netvoria spoločne. Manželia, resp. rodičia žijú $v$ dlhodobom partnerstve, no zároveň si každý udržiava svoju vlastnú domácnost'. Partneri v tzv. mingle vzt'ahu sa stretávajú vtedy, ked' majú na seba čas a chut'. Organizujú si spoločné chvíle a informujú sa o tých, ktoré preživajú osobitne. Ako ostatné tradičné páry. Iba s tým rozdielom, že ak sú spolu, tak všetko ostatné ide bokom. Mingle rodina je vel'mi náročná na dôveru a toleranciu. Takáto rodina nedáva pocit bezpečia pre menšie deti, ktoré potrebujú pevné zázemie. Mingle rodina môže zakrývat' tzv. milencov/milenky a je skôr typom akéhosi otvoreného

${ }^{14}$ E. Beck-Gernsheim, Was kommt nach der Familie?, München, Beck 2000, s. 33. 
manželstva. Je ideálny pre l'udí, ktorí pracujú v rôznych mestách, prípadne opatrujú chorých rodičov. Rodičom, ktorí vytvárajú takého typy rodín, sa často hovorí aj občasníci, mesačníci alebo týždenníci,15 podl'a toho, ako často do vlastnej rodiny zavítajú.

Negatíva mingle rodín sú:

- nezodpovednost' vo vzt'ahoch,

- benevolentnost' vo výchove detí,

- partneri sú voči sebe často tovarom ako osobami,

- rapídne sa znižuje pôrodnost' (výkyvy v demografii),

- podporovanie hedonistického a egostického správania sa,

- vytráca sa vzájomná dôvera partnerov/manželov,

- absencia pravidelného programu spolunažívania,

- zmätenost' mladších detí (súrodencov), ktorí nevedia oslovovat' nových partnerov v rodine.

Dôvody, prečo l'udia zostávajú v tzv. mingle rodinách, sú:

- zachovávanie si istej dávky nezávislosti a nezodpovednosti,

- čas na kariéru, priatel'ov a hobby,

- vzt́ah sa nedostane do stereotypu,

- rozchod sa znáša jednoduchšie.

\subsection{Rodina ako „patchwork"}

„Patchwork“ rodina je špecifickým druhom rodín. Pod pojmom patchwork sa väčšine rozumie pozošívané napr. prestieradlo z niekol'kých kusov látky. Pojem patchwork neprišiel do Európy z anglicky hovoriacich krajín, akoby sa tomu na prvý pohl'ad mohlo zdat'. Pojem patchwork sa v EÚ rozšíril práve z Nemecka, kde sa na základe textilných prestieradiel vyrobených z niekol'kých kusov látky „presunul“ tento názov na fenomén novovznikajúcich rodín. Patchwork rodina je teda "pozošívaná" podoba rodiny z rôznych rodinných príslušníkov v pokrvnom alebo nepokrvnom zväzku. Vo väčšine prípadov ide o rodiny, v ktorých členovia pochádzajú už z predošlých rodín a prichádzajú do novej, kde sú $\mathrm{v}$ podstate

${ }^{15}$ E. Beck-Gernsheim, Was kommt nach der Familie?, München, Beck 2000, s. 33-37. 
"prišití“ už k inej „látke“, k inej rodine, či už fungujúcej, alebo taktiež atomizovanej rodiny. Ide teda o rodinu "na druhý pokus", ked' ten prvý z nejakého dôvodu nevyšiel. Patchwork je veselá zošívaná deka, ale pokial' sa jedná o spolužitie a rodinu, je v tej deke vždy zašitý aj kus výbušniny (vo väčšine prípadov zložité sociálne vzt'ahy). Neustále nám rastie počet rozvodov a s nimi aj počet l'udí, ktorí hl'adajú d'alšieho partnera, aby vstúpili do „sobášneho second handu." Za posledných pät'desiat rokov sa sedemkrát zvýšil počet detí vychovávaných mimo manželstva a tento trend stále pokračuje. ${ }^{16}$ Podobne to podkladajú aj štatistický úrad na Slovensku, ktorý konštatuje, že za posledných 20 rokov sa počet rozvodov a znovuzosobášených l'udí strojnásobil. ${ }^{17} \mathrm{O}$ čo vlastne ide? Uvedieme jednu kazuistiku, ktorú sme robili v roku 2011:

Katka má 40 rokov. Vydala sa hned' po skončení strednej školy. $\mathrm{Z}$ manželstva sa narodili dve dcéry. Po 10 rokoch sa s manželom rozviedli a Katka si našla nového priatel'a Petra. Peter bol tiež rozvedený s dvoma malými det'mi z prvého manželstva. Katka a Peter sa prest'ahovali spoločne do dediny ned'aleko Prahy. Spolu majú dvojročného chlapčeka. Stabilne teda žijú v dome Katka a Peter, ich spoločný syn a mladšia dcéra z prvého manželstva Katky. Každý druhý týždeň tam navyše majú dve malé deti z prvého manželstva Petra, ktoré sú v striedavej starostlivosti s Petrovou prvou manželkou Alenou. Naviac, na víkendy prichádza Katkina najstaršia dcéra, ktorá cez týždeň chodí do školy v Prahe a býva tak u Katkinho prvého manžela. Bývalý manžel Katky, ako aj Petrova exmanželka majú tiež nových životných partnerov. Celá situácia je vel'mi zložitá, čo sa týka otázky výchovy, pretože vlastní rodičia sú prísni na vlastné deti a benevolentnejší k "cudzím“ det’om, ktoré s nimi tvoria tzv. patchwork rodinu.

Podobné príklady existujú na Slovensku už niekol'ko rokov. Podl'a štatistického úradu SR existuje viacero rodín, resp. manželstiev, ktoré sa rozviedli, opätovne sa zosobášili s inými životnými

${ }^{16}$ G. Arlt, Anthropologie und Politik, München, Wilhelm Fink - Verlag 1996, s. 34.

17 Dostupné: http://portal.statistics.sk/showdoc.do?docid=108\&words=rozvody\& $\mathrm{x}=0 \& \mathrm{y}=0$ [cit. 2.8.2012]. 
partnermi. ${ }^{18} \mathrm{~V}$ súčasnosti je na Slovensku 52\% rozvodov. Z týchto $52 \%$ rozvodov sa približne $9-10 \%$ opätovne zosobáši a vytvorí novú rodinu, ${ }^{19}$ vo väčšine prípadov ide skôr o patchwork rodinu. $\mathrm{Na}$ Slovensku je až $4 \%$ tých l'udí, ${ }^{20}$ ktorí tretíkrát uzavrú manželstvo a vytvoria tzv. patchwork rodinu. Štatistický úrad SR vo svojom Populačnom vývoji za roky 2001-2006 konštatuje, že „zastúpenie slobodných a ovdovených snúbencov sa dlhodobo mierne znižuje v prospech snúbencov rozvedených.“21 $\mathrm{Na}$ porovnanie - napr. v Nemecku22 bolo v roku 2011 až 12,5\% takýchto patchwork rodín, v ČR až 14\% z celkovej populácie. ${ }^{23}$ Štatistický úrad SR eviduje len rozvodovost', neeviduje, či $\mathrm{k}$ rozvodom prichádza viac $\mathrm{z}$ tých manželstiev, ktoré mali civilné alebo krest'anské manželstvá, resp. manželstvá, ktoré boli uzavreté s rôznymi cirkvami alebo cirkevnými či náboženskými spoločnost'ami, s ktorými má SR uzavretú zmluvu. Ked'že otázka rozvodov je skôr súdnou záležitost'ou ako štatistickou, Štatistický úrad v SR môže predbežné informácie (neúplné) o rozvodovosti podl'a civilného alebo krest'anského manželstva získat' len spätne a len na úrovni okresov, krajov, čo je vel'mi zdíhavá a prácna práca a vzhl'adom k tomu, že by sa tento úkon dal robit' iba spätne, pre súčasnost' by priniesol už neaktuálne čísla. Rozchod manželov už nie je považovaný za fatálnu prehru, naopak dochádza k tzv. „normalizácii rozvodu.“ Ludia s možnostou rozpadu manželstva viac počítajú a tomu prispôsobujú svoje životné stratégie. Napríklad: ženy sa už len málokedy venujú rodine do tej miery, aby bola ich jediným životným programom. Také postupy,

${ }^{18}$ Dostupné: http:/ / portal.statistics.sk/showdoc.do?docid=26531 [cit. 2.8.2012].

${ }^{19}$ Dostupné: http:// portal.statistics.sk/showdoc.do?docid=26531 [cit. 2.8.2012].

${ }^{20}$ Dostupné: Populačný vývoj v SR 2001-2006. In: http://portal.statistics.sk /showdoc.do?docid=26531 [cit. 2.8.2012].

${ }^{21}$ Dostupné: Populačný vývoj v SR 2001-2006. In: http://portal.statistics.sk/ showdoc.do?docid=26531 [cit. 2.8.2012].

${ }^{22}$ Dostupné: http://www.familienratgeber-nrw.de/index.php?id=1891 [cit. 2.8. 2012].

${ }^{23}$ Dostupné: http://www.genderonline.cz/uploads/3949132171ba66015aeeb530 db5568201724a68f_konference-zivotni-drahy-z-kvantitativni-a-kvalitativni-perspektivy. pdf [cit. 2.8.2012]. 
ktorými sa človek už vopred chystá na možnost' rozvodu, zároveň rozvod ul'ahčujú, a teda paradoxne podporujú. A tým, že je rozvod alebo rozchod l'ahší, dáva zároveň väčšiu možnost' nájst' si nového vol'ného partnera či partnerku. A to vedie $\mathrm{k}$ d'alším pokusom o rodinu. A k novým rozchodom, rozvodom a novým zložitejším patchwork rodinám.

Sociálne, ${ }^{24}$ existencionálne, ale aj religiózne a kultúrne spolunažívanie $\mathrm{v}$ tzv. patchwork rodinách prináša značné komplikácie. $\mathrm{Na}$ Slovensku sa tzv. patchwork rodinám dáva často prívlastok znovuobnovená alebo zrekonštruovaná rodina. ${ }^{25}$

Negatíva patchwork rodiny, čiže zošívaných rodín:

- extrémna prísnost' vo výchove vlastných detí,

- prehnaná benevolentnost' vo výchove „cudzích“ detí,

- vzniká situácia tzv. dobrých a zlých rodičov (otčim, macocha...),

- tolerancia bez hraníc („novi“" rodičia sa chcú $\mathrm{v}$ prvom rade zapáčit' sebe navzájom. No robia to prostredníctvom vlastných/nevlastných detí. Svojimi postojmi, správaním a vystupovaním často ovplyvňujú správanie svojich detí do takej miery, aby si „spriatelili“ novú stránku (manželku, deti z prvých manželstiev a pod.),

- spolunažívanie vlastných a nevlastných súrodencov. Z kazuistiky, ktorú sme popísali vyššie vyplýval vzájomný problém spolunažívania. Príklad:

Katka a Peter majú predchádzajúce vzt́ahy urovnané. No i napriek tomu, neustále narážajú na problémy rôzneho druhu. Katkina dcéra z prvého manželstva je naučená, že si televíziu môže pustit', až ked' má hotové všetky svoje povinnosti. Naopak deti z Petrovho prvého manželstva sú zvyknuté na to, že televíziu si môžu zapnút' kedykol'vek, napríklad aj $\mathrm{k}$ obedu. Z pohl'adu Katky by bolo správne rešpektovat' jej pravidlo, že sa jej dcéra na televíziu pozerá až po splnení povinností, čo sa však vel'mi t'ažko dodržiava, ked' je u nich

${ }^{24}$ G. Arlt, Anthropologie und Politik, München, Wilhelm Fink - Verlag 1996, s. 36.

${ }^{25}$ O. Sisáková, Antropologická téma v sociologickej reflexii, Prešov, Prešovská univerzita, FF 2011, s. 9-35. 
televízia zapnutá neustále. Peter však zastáva názor, že výchova jeho detí by mala byt' stabilná, takže ak sa u jeho bývalej manželky deti môžu pozerat' kedykol'vek, u nich by tomu nemalo byt' inak.

- konkurenčnost' s ex - rodinou: deti, ktoré prichádzajú do kontaktu z predchádzajúcimi rodičmi, majú často tendenciu vytvárat' v nových rodinách konkurenčný boj. Hodnotenie dobrého a zlého rodiča často záleží od toho, ktorí s rodičov dal viac (napr. po materiálnej stránke), ktorí s rodičov "popustil“ hranice výchovy, zásad a pod. Z kazuistiky z roku 2011 sme zistili aj nasledovnú informáciu o konkurencie schopnosti patchwork rodín. Príklad z jednej kazuistiky:

Naša rodina je veselý domček. Na bráne sú namal'ované kvetinky, na šnúrach visí vel’a bielizne, po záhrade behá pes a žije tu vel'ká rodina so štyrmi det'mi. Vyzerá to ideálne, až do chvíle, ked' sa pozriete len na zvonček domu. Sú na ňom štyri priezviská. Tieto štyri deti majú totiž dve mamičky a troch oteckov, k tomu jednu sestru, ktorá je s nimi len cez víkend, a potom ešte dvoch d'alších nevlastných súrodencov, ktorí $\mathrm{s}$ nami nežijú. Sú u našich prvých rodičov, resp. u nášho prvého otca alebo mamy. Vo vnútri domácnosti to je tiež zvláštne. Na prvý pohl'ad to nie je poznat'. V kuchyni sa hrajú chlapci, dva sedemroční, jeden dvojročný a jeden štvorročný, u kachlí sedí babka. Práve im natrela chlebík na desiatu a oni spokojne žujú. Nevadí ani, že z jej vnukov sú len dvaja vlastní.

- stráca sa samotný a podstatný význam rodičovstva: teda som matkou, som otcom na plný úväzok. Úloha matky a otca je v takýchto rodinách často porciovaná medzi ostatných „rodičov." Štiepi sa aj úloha zodpovednosti,

- absencia pevných hraníc rodinných tradícií, viery, hodnôt,

- manipulácia zo strany detí $\mathrm{k}$ rodičom, alebo rodičov $\mathrm{k}$ det'om,

- žiarlivost́ medzi vlastnými a nevlastnými súrodencami,

- sexuálne obt'ažovanie: v tesnej blízkosti žijú l'udia oboch pohlaví, nie sú však ochránení hradbou incestného tabu. Aktívny nemusí byt' len muž, tiež dospievajúca dcéra môže zvádzat' nevlastného otca alebo brata. ${ }^{26}$

${ }^{26}$ E. Beck-Gernsheim, Was kommt nach der Familie?, München, Beck 2000. 
Dôvody, prečo l'udia zostávajú v tzv. patchwork rodinách, čiže v zošívaných rodinách:

- vzájomná komunikácia: hlavne otázka vyjednávania, riešenia problémov, či hl'adanie kompromisov,

- jedináčikovia: jedináčikovia získajú širšiu rodinu, súrodencov,

- ekonomická funkcia rodiny: znovu obnovená, resp. pozošívaná rodina jej ekonomicky stabilnejšou ako rodiny typu single,

- schopnost' lepšej sociálnej adaptácie.

Podl'a švajčiarskych psychológov a sociológov27 sú potrebné minimálne dva roky na postupnú adaptáciu všetkých jednotlivcov, ktorí vstupujú do tzv. patchwork rodín. Dva roky sú teda skúškovým obdobím týchto rodín. Ak sa takáto rodina osvedčí, výchova detí a mládeže nezaostáva za bežnou výchovou v rodinnom prostredí. Ak sa však ideál do dvoch rokov nevytvorí, zvyčajne prichádza k rozpadu takéhoto spolužitia a opätovne vznikajú ambície k novému vzt'ahu. $V$ bežnej spoločnosti sa potom tento fenomén označuje aj ako turizmus rodín, nem. Turismus Familien. ${ }^{28}$ Pre rodičov, ktorých deti navštevujú v tzv. striedavej starostlivosti, sa v praxi zaužíval pojem víkendoví rodičia. Autorka E. Beck - Gernsheim ${ }^{29}$ d'alej dodáva, že v spoločenských kruhoch (má na mysli predovšetkým nemecky a francúzsky hovoriace krajiny) sa prestávajú používat' termíny ako exmanžel a exmanželka v novovytvorených, tzv. patchwork rodinách. Tieto „staré" termíny sa nahrádzajú názvami Vorman a Vorfrau, teda predmanžel a predmaželka (na označenie exmanželov).

\section{Odporúčanie do praxe}

1. Úlohy pre rodičov, štát a školu: spolupráca rodičov a učitel'ov je žiaduca, ale záleží na tom, aby každá skupina konala to, čo je jej zvláštnou výchovnou úlohou, ktorú z nej nemôže druhá strana

${ }_{27}$ Dostupné: http:/ / www.patchwork-familie.ch/ [cit. 2.8.2012].

${ }^{28}$ E. Beck-Gernsheim, Was kommt nach der Familie?, München, Beck 2000, s. 45 a nasl.

${ }^{29}$ E. Beck-Gernsheim, Was kommt nach der Familie?, München, Beck 2000, s. 23. 
odňat'. Každý musí prevziat' osobnú zodpovednost' za to, k čomu je on sám povolaný.

2. Zodpovednost' rodičov: zodpovednost' za diet'a, ktoré splodili je neodvolatel'ná, nevypovedatel'ná a všetko zahrňujúca; trvá tak dlho, kým diet'a nie je samostatné, dospelé, v každom ohl'ade životne zdatné a schopné niest' zodpovednost'; základné potreby detí môžu byt' najlepšie uspokojené $\mathrm{v}$ dobrých rodinách a dobrí rodičia sú spravidla nenahraditel'ní; obvykle len oni majú láskyplnú väzbu na svoje diet’a, na nich závisí istota, sebadôvera, schopnost' milovat', horlivost' v učení a morálka dietáata; len ten kto zakúsi, že je neobmedzene milovaný, bude sám schopný základnej dôvery a lásky - nielen lásky $\mathrm{k}$ iným l'ud'om, ale i lásky ku kultúre, ktorej výrazom je život jeho rodičov; štát je so svojimi školami odkázaný na to, že to budú rodičia, ktorí položia morálny a duchovný základ dorastajúcich občanov.

3. Zodpovednost' štátu, jeho škôl a učitel'ov: štát musí rodičov materiálne a morálne podporovat' tak, aby svojou výchovnou zodpovednost'ou neprenášali na verejné ústavy viac, než je pre deti dobré; verejné školy nemôžu byt' ústavmi pre celú výchovu detí; rodinu nemožno nahradit'; nemôžu plnit' ani opatrovatel'ské alebo psychoterapeutické úlohy; žiakom a štátu poskytujú najviac, ak sa sústredia na obe hlavné úlohy, pre ktoré sú nenahraditel'né: na sprostredkovanie vedomostí a zručností a na hodnotovú výchovu v rámci ústavy a základnej spoločenskej morálky; verejné školy majú súčasne slúžit' i verejným záujmom.

4. Zodpovednost' spoločnosti: spoločnost' sa musí už prestat' len prizerat' a mlčky tolerovat' často až morálne výkyvy l'udí. Dávat' väčší dôraz na prevenciu pred mediálnym násilím, pred kyberšikanovaním a sexuálnym priemyslom, ktorý často napomáha k rozpadom vzt'ahov, rodín.

\section{Záver}

Vzt'ahy v rodine nie sú vždy ideálne, avšak atmosféra rodinného prostredia musí byt' sofistikovane premyslená, pretože $v$ nej nejde len o vzájomné vzt'ahy detí a rodičov, ale kreujú sa aj základy 
ostatných budúcich vztahov, pretože diet’a si práve podl'a rodinných vztáahov vyhl'adáva a formuje vztahy nielen $\mathrm{v}$ rodinnom prostredí, v ktorom vyrastá. Rodina, i ked' je v dnešnej dobe vystavená postmodernému liberalizmu, si stále udržiava svoj kredit, hodnotu a opodstatnenie. Rodinná výchova vo všeobecnosti odráža všetko, čo sa v rodine deje. Súčasná rodinná výchova sa na jednej strane charakterizuje ako láskyplná inštitúcia, no na strane druhej prestáva vymedzovat' výchovné ciele, nanajvýš, je často zarážajúce, ak tieto výchovné ciele stanovujú deti svojim rodičom trucovaním, odhováraním a pod. Spoločnost' dovolila det'om a mládeži zdôrazňovat' ich práva na úkor ich povinností. Deti a mládež dnešnej doby nemajú alebo strácajú mantinely slušného správania, nevedia alebo nechcú vediet', čo je správne a čo je krajne nevyhovujúce. Rodina sa tak stáva vel'mi zranitel'nou (dôraz sa kladie na perfekcionizmus alebo naopak l'ahostajnost' rodičov, jednostrannost', neprimeranost' výchovných nástrojov a postupov $\mathrm{k}$ veku diet'at'a, zanedbávanie, pret́ažovanie). I vd'aka týmto aspektom sa často stretávame s názormi, že súčasná rodina a s ňou súvisiaca rodinná výchova sú v kríze. Ale pravda je kdesi ovel'a skôr, pri manželstve. Dnešní l'udia užívajú „dobrá" manželstva, no do inštitúcie manželstva sa často nehrnú, resp. vyhl'adávajú iné alternatívy (napr. konkubinát, homosexuálne zväzky a pod.), ktoré už vo svojej podstate nemôžu naplnit' podstatu manželstva a v neposlednom rade aj rodiny, a to plodenie detí. Každý deň sa nám dostávajú informácie o rozpade etických noriem spoločnosti, o rozpade manželstiev, rodín, brutalite, násilí... Spoločnost' postupne stráca kontrolu nad svojimi citmi, upadá do osamelosti a akejsi citovej otupenosti a bezohl'adnosti nielen rodinných, ale často aj pracovných vzt'ahoch. Rodičia majú upevňovat' primerané správanie, nemajú navádzat' $\mathrm{k}$ agresivite, nemajú viest' k vol'nomyšlienkarstvu svoje deti. Mladému človeku, ktorý túži po vzrušeniu a zážitkoch, asi márne predložíme správnu ideovú líniu, no i napriek tomu, môžeme urobit' dôraznú selekciu toho, čo robí, čo pozerá, čomu sa venuje a pod. Rodičia majú základné právo korigovat' výchovu. Výchova je v prvom rade rezervovaná rodičom, a nie det'om. Ak rodičia strácajú zodpovednost', je 
možné ju vyžadovat' od detí, ktoré sú im zverené? Rodič sa má stat' pre diet'a nielen kamarátom, ale i autoritou. No, autorita neznamená byt' autoritatívny. Rodičia sa nemajú len prizerat' a schval'ovat' možné výkyvy svojich detí, majú byt' regulátormi. A byt' regulátorom znamená nastavit' zrkadlo nielen det'om, ale aj sebe, spoločnosti, rodine.

\section{Zoznam bibliografických odkazov}

ARLT, G. Anthropologie und Politik. München: Wilhelm Fink-Verlag, 1996. ISBN 3770530950.

BECK-GERNSHEIM, E. Was kommt nach der Familie? München: Beck, 2000. s. 45 a nasl. ISBN 340459854.

BRUNCLÍKOVÁ, Z. Autoevalvácia vyučovacieho procesu v primárnom vzdelávaní (dizertačná práca). Bratislava: UK, 2011. 138 s.

GOGOVÁ, A., KROČKOVÁ, Š., PINTES, G. Žiak, sloboda, výchova. Nitra: Vydavatelstvo Michala Vaška, 2004. 308 s. ISBN 8080506752.

KOLDEOVÁ, L. Elektronické vzdelávanie - výzva alebo ohrozenie? In Aktuálne otázky pedagogiky (CD-zborník). Bratislav: PdF UK, 2011. s. 280. ISBN 978-80-223-3121-0.

KOSTRUB, D. Dietáa - (ako) autonómny a kompetentný subjekt. In pedagogická tvorivost' učiteliek materských škôl. Žiar nad Hronom: Aprint, 2007. s. 15-18. ISBN 978-90-80-969549-4-0.

KUDLÁČOVÁ, B. Fenomén výchovy. Bratislava: Veda, 2006. ISBN 8022409049.

LORENZ, K. 8 smrtel'ných hriechov. Praha: Panorama, 1990.

MATĚJČEK, Z. Co děti nejvíc potřebují? Praha: Portál, 1995. 108 s. ISBN 8071780065.

PALOUŠ, R. Čas výchovy. Praha: Státní pedagogické nakladatelství, 1991. s. 53. ISBN 80-04-25415-2.

PREVENDÁrovÁ, J. Rodina s postihnutým dietatóm. Nové Zámky: Psychoprof spol. s r. o., Artus, 1998. ISBN 80-976148-9-9.

ROVŇÁKOVÁ, L. Rodinná výchova a partnerské vztáahy. Banská Bystrica: MC, 2001. 63 s. ISBN 80-8041-368-1.

RozinAJOvÁ, H. Matrimoniagogika. Pedagogika rodinného života. Martin: Osveta, 1992. 246 s. ISBN 8008017686.

RozINAJOVÁ, H. Pedagogika pre rodičov. Martin: Osveta, 1988.

ROZINAJOvÁ, H. Základy rodinnej výchovy. Bratislava: SPN, 1992. 188 s. ISBN 8008013109.

SISÁKOVÁ, O. Antropologická téma v sociologickej reflexii. Prešov: Prešovská univerzita, FF, 2011. s. 9-35. ISBN 97880555003738. 
SMETANOVÁ, D. Možnosti sexuálnej výchovy (výchovy k manželstvu a rodičovstvu) za pomoci metodickej príručky [online]. Bratislava: AKO Slovensko, 2008. Dostupné na http://alternativa.sk/uploads/tx_clanok/Smetanova_PB.pdf [cit. 08.10.2011].

ŠKOVIERA, A. Malá polepšovňa (pre rodičov). Bratislava: Petrus, 2005. ISBN 8088939968.

ŠOLTÉSOVÁ, V. Médiá v kontexte súčasnej spoločnosti a katechézy (náboženskej výchovy). In Bratrská rodina. Praha: Českobratrské rodiny 63, 2004. - Roč. 36, č. 5 (2004). s. 26-27.

TAMÁšOvÁ, V. Teória a prax rodinnej edukácie. Ivanka pri Dunaji: Axima, 2007. 210 s. ISBN 978-80-969178-3-9.

TIRPÁK, P. Rodinná výchova. Prešov: Prešovská univerzita, GKTF, 2010. 146 s. ISBN 978-80-555-0142-0.

TOMÁNEK, P. Teoretické východiská rodinnej výchovy. Brno: Tribun. 165 s. ISBN 978-80-263-0233-9.

TOMÁNEK, P. Dietáa a média: novodobé otrokárstvo? Bratislava: PdF UK, Ústav pedagogický štúdií, Katedra pedagogiky a sociálnej pedagogiky. In Deti v tažkúch životných situáciách. s. 174-181. ISBN 978-80-223-3187-6.

TOMÁNEK, P. Kyberšikana ako aktuálny problém v súčasnej rodinnej výchove. In Lifelong learning, roč. 1, č. 2, s. 30-43. ISSN1804-526X.

TOMÁNEK, P. - TOMÁNKOVÁ, M. Manželstvo a legalizované partnerstvá v súčasnej Európe. In Fórum sociální práce 2011, č. 2. s. 39-59. ISSN1804-3070.

Zákon č. 154/1994 Z.z. NR SR o matrikách, druhá čast' - paragrafy § 27-30.

ŽILÍNEK, M. Éthos a utváranie mravnej identity osobnosti. Bratislava: Iris, 1997. ISBN 8088778603 .

Použité internetové zdroje

http://portal.gov.sk/Portal/sk/Default.aspx?CatID=39\&aid=128 [cit. 06.09.2011]. http:/ /queering.wordpress.com/2005/12/11/najnovsi-prieskum-verejnej-mienkyneprekvapil-slovaci-nie-su-k-homosexualom-velmi-tolerantni/ [cit. 03.09.2011]. http://www.euractiv.sk/rovnost-sanci/clanok/registrovane-partnerstvo-uz-aj-vcechach [cit. 06.09.2011].

http://www.ganymedes.info/archiv2006/rok2006.asp?intClanek=6 [cit. 06.09.2011] http:// portal.statistics.sk/showdoc.do?docid $=108 \&$ words $=$ rozvody $\& x=0 \& y=0$ [cit. 2.8.2012].

http:/ / www.familienratgeber-nrw.de/index.php?id=1891 [cit. 2.8.2012].

http://www.patchwork-familie.ch/ [cit. 2.8.2012].

http://www.genderonline.cz/uploads/3949132171ba66015aeeb530db5568201724a6

8f_konference-zivotni-drahy-z-kvantitativni-a-kvalitativni-perspektivy.pdf [cit. 2.8.2012]. 


\section{Nowe rozwijające się formy życia rodzinnego w Słowacji}

\section{Streszczenie}

Przedstawiciele różnych dyscyplin naukowych, w prowadzonych nad współczesną rodziną badaniach, koncentrują się wokół rodzicielstwa i aktualnych form tworzenia rodziny. Praca daje wgląd w fenomen współczesnych typów rodzin: samotne rodzicielstwo, rodziny mieszane i zrekonstruowane. W artykule zaprezentowano definicje rodziny i wychowania w rodzinie. Podjęto rozważania na temat wychowania, roli rodziny i modeli rodziny, jakie współcześnie funkcjonują w Słowacji. Obecnie coraz więcej rodzin to rodziny typu patchwork oraz rodziny mieszane. Takie modele rodziny niosą $\mathrm{z}$ sobą różne konsekwencje dla funkcjonowania i kondycji jej członków. Innym ważnym problemem podejmowanym w artykule są rodziny typu „singiel“ - kobieta pragnie dziecka, ale nie chce wiązać się na stałe, tworzyć związku oraz budować rodziny. Przedstawiono zagrożenia dla funkcjonowania takiej rodziny. W tekście odnaleźć można także implikacje do działań pedagoga na polu rodzin, o których mowa w publikacji.

Słowa klucze: rodzina, edukacja, samotne rodzicielstwo, rodzina mieszana, rodzina zrekonstruowana 